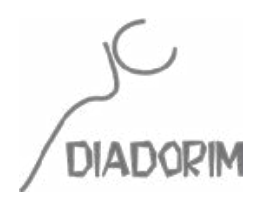

\title{
ABORDAGEM SOCIOCOGNITIVO-DISCURSIVA DE MECANISMOS REFERENCIAIS DÊITICOS PRONOMINAIS NOS LIVROS DIDÁTICOS DO ENSINO MÉDIO
}

\author{
Maria Margarete Fernandes de Sousa ${ }^{1}$ e Ana Cátia Silva de Lemos ${ }^{2}$
}

\section{RESUMO}

Investigar as relações textuais que são construídas pelos elementos dêiticos é fundamental para o ensino, pois apreender essas relações pode auxiliar os alunos na sua proficiência de leitor e de escritor. Dessa forma, entendemos que é crucial para a aprendizagem que o material de ensino observe o vínculo dos elementos dêiticos com os contextos discursivos. Assim, neste artigo, analisamos como os livros didáticos do Ensino Médio, em suas atividades sobre os elementos dêiticos pronominais, consideram as circunstâncias social, cognitiva e discursiva que se relacionam com os processos dêiticos da linguagem e como as atividades orientam para a compreensão adequada dos mecanismos de referenciação dêitica. Esta pesquisa tem caráter indutivo, pois, para observar as peculiaridades do fenômeno da dêixis, nas atividades de análise linguística, partimos de constatações particulares, fornecidas pelas teorias de base (MONDADA; DUBOIS, 2003; CAVALCANTE, 2000, 2011; KOCH, 1993, 2004; BEAUGRANDE; DRESSLER, 1981; MARCUSCHI, 2008; COSTA, 2007, entre outros autores relevantes para a área), que podem sinalizar para constatações mais abrangentes, generalizantes. Com respeito à análise das atividades, pautamo-nos na teoria da competência comunicativa defendida por Habermas (1989), que dialoga com a abordagem de ensino sociocognitivo-discursiva (CAVALCANTE; CUSTÓDIO FILHO; BRITO, 2014). Assim, averiguamos, no corpus selecionado, se o ensino dos mecanismos dêiticos corrobora com a abordagem teórica na qual nos embasamos, com a qual concordamos. Para isso, analisamos atividades de cinco coleções didáticas, selecionadas no manual do Programa Nacional do Livro Didático (PNLD), de cujos livros selecionamos 29 atividades de análise linguística que tratam do ensino de pronomes pessoais e de tratamento. A análise nos mostra que esses livros didáticos do Ensino Médio adotam um tratamento essencialmente gramatical no tocante ao ensino das estruturas referenciais dêiticas e tangenciam as

\footnotetext{
1 Professora Adjunto do Departamento de Letras Vernáculas e do Programa de Pós-Graduação em Linguística da Universidade Federal do Ceará (UFC). Coordenadora do Grupo de Pesquisa Gêneros Textuais: Perspectivas Teóricas e Metodológicas/GETEME/UFC.

2 Professora da rede particular de ensino em Fortaleza-Ce, Mestre em Linguística pelo Programa de Pósgraduação em Linguística da Universidade Federal do Ceará (UFC), Integrante do Grupo de Pesquisa Gêneros Textuais: Perspectivas Teóricas e Metodológicas/GETEME/UFC.
} 
funções enunciativas que compõem a essência desses mecanismos. Dessa forma, atribuímos ao ensino de língua portuguesa apresentado pelos livros didáticos do Ensino Médio analisados um caráter, predominantemente, normativo da língua, privilegiando esse aspecto em detrimento do caráter funcional da linguagem.

PALAVRAS-CHAVE: Referenciação; dêixis; livro didático.

\section{RÉSUMÉ}

Pour examiner les relations textuelles qui sont construites par les éléments dêiticos sont fondamentales pour l'enseignement, parce qu'appréhender ces relations il peut aider les étudiants dans sa/sa compétence de lecteur et d'auteur. De cette façon, nous avons compris qu'est crucial pour la relation apprenante que le matériel pédagogique observe le lien des éléments dêiticos avec les contextes discursifs. De cette façon, nous avons analysé comme les livres de texte de l'Enseignement de Moyen, dans leurs activités sur les éléments dêiticos pronominais, ils considèrent les circonstances : social, cognitif et discursif, que ils liez avec les processus dêiticos de la langue et si les activités collaborent pour la compréhension appropriée des mécanismes de referenciaç ão dêitica. Cette recherche a le caractère de recherche inductif, parce que, pour observer les particularités du phénomène du dêixis dans les activités d'analyse linguistique, nous sommes partis de vérifications privées, fournies selon la théorie de base et nous avons cherché pour découvrir, dans le corpus choisi, si l'enseignement des mécanismes dêiticos corrobore avec l'approche théorique dans le que nous avons nous basé. Nous avons analysé cinq collections didactiques, choisies dans le manuel du Programme national du livre Didactique, (PNLD) dans ces livres que nous avons surlignés et nous avons analysé 29 activités d'analyse linguistique qui examinent l'enseignement de pronoms personnels et de traitement. Dans la défense pour un enseignement des processus de reference dêitica qui considère ces aspects, nous avons assumé la perspective de reference protégé pour Mondada et Dubois (2003), Cavalcante (2000 2011), Koch (19932004), Beaugrande et Dressler (1981), Marcuschi (2008), Costa (2007). En ce qui concerne l'analyse des activités, nous sommes décidés pour la théorie de la compétence communicative augmentée créée par Habermas (1989), qu'elle dialogue avec l'approche enseignante (CAVALCANTE; CUSTÓDIO FILHO; BRITO, 2014). Lanalyse dans l'affichage que quelques livres didactique de l'Enseignement de Moyen adoptent un traitement essentiellement grammatical concernant l'enseignement des structures referenciais dêiticas et tangenciam les fonctions enunciativas, que vous composez l'essence de ces mécanismes. De cette façon, nous avons attribué à l’enseignement de langue portugaise présentée par le livre de texte du Moyen Enseignant un caractère, principalement, normatif de la langue, favorisant cet aspect au détriment du caractère fonctionnel de la langue.

MOT-CLÉS: Reference; dêixis; livre didactique.

\section{Introdução}

Os estudos e as reflexões sobre referenciação nos mais diversos gêneros (e-mails, cartas, anúncios etc.) vêm ampliando, consideravelmente, o material teórico e metodológico dessa área de estudo. Como exemplos dessa realidade, citamos os trabalhos de Marcuschi (2008), Koch (2004), Cavalcante $(2000,2011,2013,2014)$ que têm expandido o conhecimento sobre esse assunto para além do ambiente acadêmico. 
Apesar disso, as pesquisas nesse campo podem ser mais bem exploradas, sobretudo, no meio escolar. Haja vista que professores e o próprio livro didático (LD) parecem, ainda, muito confusos quanto à abordagem dessas teorias, através de relações pouco conhecidas dos profissionais de ensino, logo, pouco praticadas também.

As relações textuais de sentido são estabelecidas por diversos elementos estruturais da língua que ajudam a marcar as situações construtoras dos sentidos do texto, dentre eles destacamos o mecanismo da dêixis, marcador de pessoa, de espaço, de tempo e das relações hierárquicas estabelecidas no discurso em que os textos são construídos, os quais denominamos de dêiticos pessoais, espaciais, temporais e sociais.

Investigar as relações textuais que são construídas por esses elementos, é fundamental para o ensino, pois apreender essas relações pode auxiliar os alunos na sua proficiência de leitor e de escritor. Dessa forma, entendemos que é crucial para a relação de aprendizagem que o material de ensino observe o vínculo dos elementos dêiticos com os contextos discursivos.

O livro didático é uma ferramenta que auxilia a prática dos profissionais em sala de aula. E, embora reconhecendo que a aula de português não se faz apenas com o uso do livro didático, sabemos que um bom material de apoio, como o LD, ainda é motivo de reivindicação da classe do magistério, por isso enfatizamos a importância do material didático se renovar com novas teorias e abordagens do ensino de Língua Portuguesa que promovam a reflexão no uso dos mecanismos da língua no processo de construção dos sentidos de textos.

Como processo de construção textual, destacamos a Referenciação que, segundo Cavalcante (2013, p.102, grifos da autora), é a "ação de referir". Essa ação envolve processos referenciais, como a anáfora e a dêixis. A atenção deste trabalho centra-se nos processos referenciais dêiticos e na maneira como eles são abordados nos LD por serem, também, mecanismos importantes na estrutura textual, bem como, por comporem a coesão e a coerência dos textos. Além disso, julgamos que o ensino dessas estruturas, no Ensino Médio, deixa de lado alguns aspectos importantes da referenciação para sua compreensão, como o traço da subjetividade mencionado por Ciulla (2008), ao qual retornaremos posteriormente.

Como apontamos, a perspectiva de Mondada; Dubois (2003) credita aos processos de referenciação uma relação entre os aspectos sociais, cognitivos e discursivos da linguagem, caracterizando a referenciação como um processo dinâmico em construção com os participantes da interação discursiva.

$\mathrm{Na}$ busca por um ensino dos processos de referenciação dêitica que considere esses aspectos, assumimos a perspectiva de referenciação defendida por Mondada; Dubois (2003), Cavalcante (2000, 2011), Koch (1993,2004), Beaugrande; Dressler (1981), Marcuschi (2008), Costa (2007), que defendem a referenciação como um processo discursivo, cognitivo, construído discursivamente, a partir da interação.

Assim, pretendemos com esta pesquisa defender uma abordagem de ensino sociocognitivodiscursiva quanto aos elementos referenciais dêiticos, uma vez que a apropriação do uso, bem como a compreensão desses elementos dá-se a partir do conhecimento contextual desses mecanismos, pois compreender o uso dos elementos dêiticos de forma simplista, predominan- 
temente gramatical, sem encará-los como mecanismos construídos sociocognitivamente no discurso pode interferir na formação de leitor e, consequentemente, do escritor competente levando o aluno a escrever textos sem a clareza e sem a objetividade necessárias, duas características indispensáveis à textualidade.

Assim, examinamos se os livros didáticos do Ensino Médio, em suas atividades de análise linguística, consideram o caráter sociocognitivo-discursivo dos elementos dêiticos pronominais, sobretudo dos dêiticos pessoais, em suas circunstâncias: social, cognitiva e discursiva, que se relacionam com os processos dêiticos da linguagem e se as atividades orientam o aluno para a compreensão adequada dos mecanismos de referenciação dêitica.

Enfim, pretendemos expor como se dá nos LDs do Ensino Médio, a apropriação dos mecanismos referenciais dêiticos, a fim de verificar se os LDs disponibilizados pelo Ministério da Educação (MEC) mantêm-se atuais com as novas abordagens de ensino da língua portuguesa. Para tanto, analisamos cinco coleções didáticas do Ensino Médio brasileiro, disponibilizadas pelo MEC, as quais foram as mais escolhidas pelos professores da rede pública, quando do Programa do Livro Didático de 2012 (PNLD - 2012). Destas, selecionamos e analisamos 29 atividades a partir da abordagem sociocognitivo-discursiva e dos critérios de análise para elaboração de atividades de análise linguística desenvolvidos por Campos ( 2014).

Atualmente, o ensino de Língua Portuguesa está baseado no desenvolvimento das competências do aluno. Apresentamos melhor nossa concepção de competência no decorrer deste trabalho, debatendo conceitos que orientam nossa análise, bem como, os que são indicados pelos Parâmetros Curriculares.

No intuito de clarificarmos o conceito de competência comunicativa com o qual trabalhamos nesta pesquisa, apresentamos a seguir a teoria da Ação Comunicativa proposta por Habermas (1989).

\section{Competência comunicativa e dêixis}

O ensino básico brasileiro é incentivado, através dos documentos oficiais, a desenvolver as competências e habilidades dos alunos e é norteado pelos Parâmetros Curriculares Nacionais (PCNs). Como mencionamos anteriormente, os parâmetros do ensino brasileiro indicam que a aprendizagem deve ser pautada pelo conhecimento prévio dos alunos e, a partir dele, o professor deve desenvolver e utilizar a linguagem nos três níveis de competências sugeridas pelos PCNs: interativa, gramatical e textual.

É importante frisar que, em linguagem, o termo competência remete a teorias que se propuseram a estudar e defender abordagens diferentes, nesta pesquisa, os pressupostos de Habermas, Chomsky e a abordagem pragmática dos atos de fala ${ }^{3}$ nos interessarão mais detalhadamente. Apesar desta pesquisa não ter como foco principal analisar essas teorias, acreditamos que é necessário compreender como se dá a apreensão da competência na linguagem, sobretudo, no tocante à análise dos mecanismos dêiticos, uma vez que esses elementos mantêm estreita relação

\footnotetext{
3 Chama-se Teoria dos Atos de Fala o estudo iniciado pelo filósofo da linguagem Wittgenstein sobre a validade das sentenças na linguagem, cuja pesquisa foi ampliada pelos estudos dos filósofos J. R. Searle e J. L. Austin, quando a teoria ganhou essa denominação e passou a ser definida como o estudo "sistemático da relação entre os signos e seus intérpretes" (ARMENGAUD, 2006, p.100), em uma definição mais simples, consideramos essa teoria como o estudo dos usos dos vocábulos em diferentes contextos linguísticos que determinam seus sentidos.
} 
com os processos enunciativos que permeiam a linguagem.

Essas teorias estão inseridas no âmbito das abordagens estruturalistas, gerativistas e funcionalistas da linguística, que consideram a competência linguística tanto no âmbito mais gramatical, quanto no âmbito da ação comunicativa. Quanto ao primeiro aspecto, somos defensores, conforme Baltar (2004), de que o domínio do conhecimento humano ultrapassa os limites do formalismo gramatical; por outro lado, também acreditamos que a competência linguística não reside apenas no caráter morfológico da linguagem, mas, principalmente, no caráter comunicativo e interativo da linguagem.

O termo competência em linguística remete quase que, instantaneamente, para os estudos de Chomsky (1959), para quem a competência tem relação com a capacidade de falantes ideais dominarem um sistema de regras e, a partir delas, gerarem sentenças infinitas. A teoria do linguista americano propõe que a linguagem não seja observada como um fenômeno coletivo, mas como o resultado dos usos e da criatividade de cada falante, a linguagem para Chomsky (1959) é uma maneira de exprimir pensamentos e não um sistema social.

Por não considerar os aspectos sociais relevantes para sua teoria, Chomsky (1959) recebeu muitas críticas, que o fizeram remodelar sua proposta e, mesmo deixando de lado aspectos pragmáticos e semânticos, ampliou sua teoria e desenvolveu a dicotomia competência vs desempenho. A partir dessa nova perspectiva, o conceito de competência comunicativa ganha novos parâmetros, pois a definição de Chomsky (1959) passa a ser considerada, para muitos pesquisadores, uma problemática na obra do linguista americano, por isso, muitos estudiosos da linguagem tentaram reparar essa falha. Um deles é Habermas (1989), que criou a teoria da competência comunicativa.

Comungamos com essa teoria, pois acreditamos que a chave para a compreensão dessa abordagem é a subjetividade discursiva, encontrada nas práticas cotidianas da linguagem. Por isso, defendemos que a teoria da Ação Comunicativa de Habermas colabora para a compreensão dos elementos dêiticos pronominais, que são essencialmente subjetivos.

Espelhando-se na Teoria dos Atos de Fala, Habermas utiliza critérios pragmáticos e baseia-se nessa teoria para afirmar que a linguagem se concretiza a partir de implicações pragmáticas, que seriam as condições para desempenho do discurso que falante e ouvinte precisariam considerar. Segundo Boufleur (1996), com quem concordamos, Habermas entende o processo de compreensão, a partir das relações sociais estabelecidas pelo discurso. Nas palavras de Boufleur (1996), a proposta habermasiana requer que:

Para entender-me linguisticamente com alguém sobre algo, eu espero que esse alguém me compreenda e reconheça que falo conforme a verdade dos fatos, de forma sincera, isto é, conforme minha convicção, e que aquilo que digo é justo, ou seja, que estou autorizado a pedir que nossos comportamentos e relações sejam de acordo com o dito. $\mathrm{O}$ ato de fala, desse modo, transforma-se na sede de uma racionalidade em que o falante apresenta pretensões de validez, preenche as condições das mesmas e pressupõe ter razões capazes de resgatá-las discursivamente (1996, p.37).

Habermas (1989) acredita que, no ato de realização, as frases deixam de ter apenas um caráter linguístico e passam a exercer um poder sobre o contexto e a interação, por isso, ele julga que a competência não é apenas linguística, como afirma Chomsky, posto que ela exerce influência no ato comunicativo. Por isso, o filósofo caracteriza a competência como uma atividade comu- 
nicativa, ao considerar que ela é uma ação comunicativa. Habermas (1989) estabelece que a competência é uma ação realizada a partir de aspectos intersubjetivos que permeiam a linguagem, dessa forma, a competência comunicativa é construída em um processo partilhado pelos falantes; assim, afirma:

O peculiar deste mecanismo que é o entendimento intersubjetivo é que ego [...] pode motivar racionalmente suas ofertas, quer dizer, pode motivá-lo porque está disposto a respaldar com razões a pretensão que levanta ou faz valer. Em lugar de sanções ou gratificações com que na ação estratégica pode influir sobre a situação de decisão do outro, na ação comunicativa o que há detrás das pretensões de validez, reciprocamente levantadas não são armas, nem bens, mas razões potenciais (HABERMAS, 1989, p. 460).

Segundo o autor (1989), as mudanças ocasionadas pelos estudos pragmáticos e pela reviravolta linguístico-pragmática ${ }^{4}$ geraram uma transformação no paradigma da linguagem, fazendo com que esta passe a ser considerada como "uma relação intersubjetiva" (HABERMAS, 1989, p.392). Dessa forma, pensar na linguagem deixa de ser um fato considerado solitário e passa a ser observado como um processo compartilhado por indivíduos que se situam em uma mesma cultura e sociedade. Esse pressuposto habermasiano implica que as interpretações de uma determinada sentença ou de uma forma linguística, que se apoia nos contextos de uso, como os dêiticos, por exemplo, variam conforme as crenças, os valores e os contextos social e cultural nos quais os indivíduos se situam.

Com isso, ele cria sua teoria da ação comunicativa, unindo os pressupostos pragmáticos e a teoria dos atos de fala com a filosofia hermenêutica, pois essas correntes de pensamento consideram que a compreensão do enunciado é realizada mediante a dimensão da linguagem, uma vez que a compreensão dos enunciados só poderá ser concretizada diante da intersubjetividade que está na linguagem.

Acreditamos ser importante considerar a perspectiva habermasiana em nossa análise dos elementos dêiticos, pois esses elementos ganham sentido conforme o contexto e a prática de usos, o valor semântico dessas formas é dependente das relações sociais, culturais e discursivas estabelecidas no contexto, na situação de fala.

Habermas (1989) considera a situação de fala como uma âncora entre falante e ouvinte, para ele: "um falante, ao comunicar-se com um ouvinte sobre algo, dá expressão àquilo que ele tem em mente" (1989, p.40), assim, acreditamos que só é possível chegar ao valor significativo dos elementos dêiticos, quando se reconhece essa "expressão" que Habermas (1989) identifica.

Habermas articula a teoria dos atos de fala, restaurando-a com o conceito de "mundo vivido", criado por ele. A teoria de Habermas (1989) demanda que o sistema social coloniza o saber vivenciado por cada indivíduo em sociedade, o que faz esse saber ser compartilhado e ser capaz de conduzir ao entendimento dos significados. Para Habermas (1989), ponto de vista com que concordamos, o "mundo vivido" é o local onde os falantes constroem a compreensão, portanto, ele é uma condição no processo comunicativo. Oliveira (1996) define o "mundo vivido" em Habermas como:

[...] o horizonte de possibilitação no qual já sempre se situam os que agem

\footnotetext{
4 Também conhecida como virada linguística, a reviravolta linguística pragmática foi o momento histórico, ocorrido durante o século XX, em que a linguagem ganhou destaque e passou a ser concebida como objeto central necessário para todo e qualquer saber humano.
} 
comunicativamente: ele é o pano de fundo não explicitado do agir comunicativo e, enquanto tal, o depósito cultural de convicções de uma comunidade humana, o lugar onde se movimentam os que agem comunicativamente. Portanto, as estruturas do mundo vivido estabelecem as formas de intersubjetividade (1996, p. 335).

Habermas (1989) ainda esclarece que o mundo vivido é composto por dimensões que estabelecem e dão razão à sua existência, essas dimensões fazem parte do aspecto cultural, social e cognitivo da linguagem, características que marcam os critérios da análise dos elementos dêiticos nesta pesquisa e que, segundo ele, criam condições para a prática da linguagem, nas palavras do autor:

O mundo é "dado" para nós como um mundo "idêntico para todos", a prática linguística nos leva a essa constatação, o sistema linguístico é estabelecido por essas convenções sociais, o contrato social que intermedeia as relações linguísticas é único em cada cultura, pois depende de traços socioculturais (HABERMAS, 1989, p.39).

As dimensões que compõem o mundo vivido, mencionado por Habermas (1989), podem se relacionar com o conhecimento referencial ou comunicacional, citado por Carvalho e Sousa (2014), pois para essas autoras a competência comunicativa está associada ao desenvolvimento de três grandes sistemas de conhecimentos, quais sejam: Conhecimento linguístico; Conhecimento referencial; Conhecimento sobre estruturas ou modelos textuais globais.

Para Carvalho e Sousa (2014), o conhecimento linguístico está relacionado ao reconhecimento das estruturas da língua em funcionamento na linguagem, englobando os conhecimentos gramatical e lexical, "Sendo assim o responsável pela articulação entre som e sentido da língua" (2014, p.93). O conhecimento referencial é, para esta pesquisa mais relevante, pois "associa-se aos saberes sobre o mundo", esse conhecimento considera o saber que o indivíduo tem, ao chegar no ensino escolar, uma vez que, ao iniciar o ensino escolarizado, o aluno já domina o sistema da língua, desconhecendo, em alguns casos, o código linguístico, por isso, julgamos esse aspecto mais relevante, para esta pesquisa, pois os elementos dêiticos têm seus sentidos construídos em situações de uso, dado que o aluno, quando chega à escola, já os conhece, mas desconhece, em alguns casos, os usos instituídos pela norma que em muitos livros didáticos predominam. O conhecimento sobre estruturas ou modelos textuais globais envolve os conhecimentos que se relacionam ao reconhecimento de gêneros e tipos textuais, uma vez que o indivíduo não alfabetizado, mas detentor da competência comunicativa pode reconhecer gêneros textuais em seus contextos de uso.

Portanto, utilizamos o suporte teórico da teoria da ação comunicativa, idealizada por Habermas (1989), bem como os conhecimentos mencionados por Carvalho e Sousa (2014), para observar se a atenção com a competência comunicativa está, de alguma forma, inserida nas atividades de análise linguística dos livros didáticos, uma vez que a competência comunicativa fornece autonomia aos falantes para se posicionarem e dominarem adequadamente as formas linguísticas em diversos contextos ou "mundos vividos".

Certamente por julgarem importante a apropriação adequada da competência os PCNs trazem esse critério como um dos que devem nortear o ensino de língua materna, assim, os PCNs abordam a questão do desenvolvimento da competência comunicativa nas aulas de língua portuguesa.

Os avanços nos estudos de Linguística de Texto colaboraram com essa visão, assim, o texto não pode ser considerado um objeto estanque, sem relação com as experiências interacionais e pes- 
soais do falante. É importante ressaltar que os PCNs não desaconselham e nem desprestigiam o ensino da gramática normativa, consideram-no relevante em contextos específicos de uso, pensamento que partilhamos e com o qual concordamos.

Destacamos que considerar importante o desenvolvimento da competência comunicativa nos alunos também deve ser um aspecto da formação dos professores que vão lecionar língua materna, pois, de acordo com Carvalho e Sousa (2014, p. 93):

[...] é ainda muito pouco trabalhada [a noção de competência comunicativa], na formação de professores, o que é uma pena, uma vez que reflexões sobre a construção da competência comunicativa lhe permitiriam compreender os processos de aprendizagem da linguagem em relação ao processo global [de aprendizagem], considerando os pontos de articulação entre o cognitivo (o individual) e o social (o coletivo), assim como a base social a partir da qual são construídas as representações individuais como a capacidade de interagir em diferentes situações e, portanto, de produzir e receber textos.

Logo, o ensino das estruturas dêiticas, bem como dos demais processos de referenciação, deve considerar os contextos de usos adequados para que sua compreensão atinja e amplie a competência comunicativa dos alunos. No tópico seguinte, demonstraremos como o conhecimento do contexto é fundamental para a apreensão adequada dessas estruturas, focando nos elementos dêiticos, objetos de estudo desta pesquisa e na abordagem sociocognitivo-discursiva em que nos embasamos.

\section{Referenciação e construção de sentidos}

Com os estudos mais críticos a respeito da língua, a linguagem passou a ser pesquisada cientificamente, buscou-se métodos e procedimentos coerentes com esse tipo de abordagem. Uma das operações utilizadas na observação da língua como ciência foi a delimitação dos elementos através da segmentação e da substituição das formas linguísticas; com essa operação, o texto era observado em suas partes, as quais eram divididas em classes de fonemas a nas relações sintagmáticas presentes, com isso, os estudos sobre a linguagem avançaram até alcançarem um ponto em que os aspectos da enunciação ganhariam ênfase na análise da língua.

A partir da virada pragmática, os estudos linguísticos passam a olhar os fatos da língua sob a ótica do sentido, do significado - apesar do sentido ser fundamental para demarcar as diferenças básicas em que se norteiam estudos estruturalistas e formalistas, por exemplo, antes da virada podemos considerar o sentido como coadjuvante nas abordagens que focavam suas pesquisas na ordenação e sistematicidade da classificação da língua, sobretudo, o aspecto social do sentido, dado que este se constrói pelo uso nativo da língua (BENVENISTE, 1976, p. 137).

Nessas práticas de interação dos sujeitos estão inseridos os procedimentos enunciativos mencionados por Benveniste. Essas características mantêm relação com os processos referenciais, objeto de nossa pesquisa (os dêiticos), dado que esses elementos são instaurados no processo enunciativo; dessa forma, apoiamos os fatos a seguir citados, mencionados por Geraldi (1996, p. 13), nos quais estão elencados os acontecimentos que orientam a enunciação:

O fato de que, depois da enunciação, a língua efetua-se numa instância do discurso; O fato de que, uma vez se declare locutor e assuma a língua, o locutor implanta o outro diante de si;

O fato de que, na enunciação, a língua se acha empregada para a expressão de uma certa relação com o mundo; 
O fato de que a mobilização e a apropriação da língua se dão pela necessidade de o locutor referir, pelo discurso e para o alocutário, a possibilidade de co-referir identicamente, "no consenso pragmático que faz de cada locutor um co-locutor".

Acreditamos que essas características, citadas por Geraldi (1996), estão imbricadas nos processos de referir e na apropriação desses processos pela linguagem como uma prática de negociação intersubjetiva frente à construção de sentidos pelos indivíduos.

Podemos atestar isso com Benveniste (1976) para quem a ordenação do sistema linguístico obedece a normas sociais determinadas pela comunicação intersubjetiva, através das quais os falantes consideram os usos da língua em seus contextos sociais e culturais. Com isso, a realidade, inerente ao processo dialógico dos falantes, reflete uma troca na qual a linguagem não reproduz a realidade pela qual os objetos do mundo são referidos (BENVENISTE, 1976, p.26).

Dessa forma, o sistema da linguagem insere, no processo de se referir a algo, um filtro nas mentes de seus usuários, através do qual cada indivíduo reflete sua experiência com o mundo: "A referência passa a ser considerada uma relação ligada ao enunciado [...] aplicada às expressões em contexto" (LYONS, 1977a, p.171). Esse processo é denominado por Mondada;Dubois (1995) como referenciação. Com essa definição, os estudos sobre essa temática evoluíram e superaram a perspectiva lógico-filosófica de que os objetos estão postos no mundo e que têm uma significação pré-definida.

De acordo com Mondada;Dubois (2003), os processos referenciais são práticas que envolvem aspectos de ordem cognitiva, social e discursiva. Esses processos estão relacionados com todo sujeito incluído em um universo de linguagem, como afirmam os autores:

Estas práticas não imputáveis a um sujeito cognitivo abstrato, racional, intencional e ideal, solitário face ao mundo, mas a uma construção de objetos cognitivos e discursivos na intersubjetividade das negociações, das modificações, das ratificações de concepções individuais e públicas do mundo (2003, p.20).

Acreditamos que o aspecto discursivo soma-se aos aspectos cognitivo e social, mencionados pelos autores acima citados, pois marca a cena enunciativa e os componentes linguísticos do discurso; estes são importantes para nós, pois serão analisados, conforme o contexto das atividades dos livros didáticos. Outro importante aspecto da referenciação é mencionado por Leal (2015, p. 25), que relaciona as características dos processos referenciais com as práticas de ensino, para a autora:

O advento dessa teoria trouxe ao meio escolar um entendimento primário da importância dessas relações textuais, menos pela prematuridade de seus fundamentos, e mais pelos efeitos reducionistas ainda hoje presentes em alguns livros didáticos que privilegiam apenas o aspecto sintático-semântico dessas relações sem considerar que os elementos do texto e do discurso são interligados e coabitam o mesmo plano, compondo a própria dimensão discursiva.

É possível notar a preocupação da autora com a maneira pela qual a teoria proposta por autores como Mondada;Dubois (2003) foi apreendida no ambiente escolar. Concordamos com Leal (2015) e acreditamos que a apreensão do conteúdo na maioria dos livros didáticos analisados referentes às práticas de referenciação se deu de forma reduzida, deixando de lado aspectos importantes desses processos, como o caráter enunciativo dos dêiticos, por exemplo. Assim, reconhecemos a importância de considerar essa abordagem teórica também defendida por Silva (2014, p. 125-126): 
Sob essa perspectiva, a referência nunca é acessada anteriormente à interação; dar-se-á mediante uma coconstrução referencial dos participantes em uma enunciação. Por isso, essa perspectiva nega a ligação direta entre linguagem e realidade, em que aquela funcionaria como um espelho desta, para defender a construção referencial como dependente de um momento enunciativo em que se encontram presentes, em um contexto específico, sujeitos constituídos sócio-histórico e culturalmente, por isso, sujeitos ideológicos.

Dessa forma, a perspectiva de referenciação que adotamos considera a construção dos processos referenciais um processo no qual estão inseridos os aspectos cognitivos, sociais, culturais e discursivos. Entendemos que somente com a atuação interdependente desses elementos é possível acessar o sentido dos processos referenciais, que é construído nessa relação. Por isso, também nos apoiamos em Costa (2007, p. 34), para quem: “a interação entre o uso individual da linguagem e as práticas sociais não pode ser rompida, pois a língua se materializa na práxis" (grifo nosso). Portanto, esses níveis reúnem características enunciativas, sem as quais não é possível, para o falante, compreender o uso de certas estruturas, como as estruturas dêiticas.

Para Cavalcante; Custódio Filho; Brito (2014), por não separar esses dois níveis (Cognição e Social), a designação mais apropriada para essa proposta será Sociocognitivo-discursiva, pois a construção de sentido dos textos perpassa o meio social, o cognitivo e o aspecto do discurso estabelecido; com que concordamos, uma vez que não a consideramos conflitante com a perspectiva defendida por Mondada; Dubois (2003), por isso, a consideramos complementar e, portanto, também será adotada por nós.

Assim, nosso foco recai, prioritariamente, na compreensão dos elementos referenciais desses autores, que nos propomos a estudar, pois suas propostas estão galgadas na relação dos valores enunciativos, que reconhecemos nos elementos dêiticos, perspectiva também apoiada em outros importantes teóricos, como Bronckart $(1999,2012)$, que associa a linguagem a um lado da vida social, perpassado por outros elementos da esfera cultural. De acordo com este autor, as relações e interpretações da linguagem são configuradas como:

Representações pessoais referentes às normas sociais e à imagem que convém dar de si mesmo orientam a escolha dos signos dentre as diversas possibilidades que uma língua oferece para semantizar um mesmo referente; em outros termos, orientam a seleção dos signos no interior dos paradigmas de unidades que, em língua, remetem a um mesmo universo de referência (BRONCKART, 2012, p.47).

O posicionamento de Bronckart coaduna com a postura de Apothéloz (2001), para quem a construção dos processos referenciais depende da interação do meio social, pois é a partir dela que ocorre a negociação para a escolha das "possibilidades que a língua oferece", como observa Bronckart (2012).

Por considerar o que esses autores asseveram, julgamos que preocupações meramente estruturais nas análises de textos perderam espaço para abordagens como essas que encaram o texto e seus mecanismos de forma crítica, como um "processo em seu contexto de enunciação" (MOTTA-ROTH, 2007b, p. 4).

É dessa forma que pretendemos identificar os processos de referenciação, neste trabalho: como mecanismos que surgem nos processos enunciativos e marcam as intenções dos sujeitos envolvidos nessas relações. Logo, os elementos referenciais emergem de situações sociais, construídas por sujeitos que estabelecem esses mecanismos, a partir do universo sociocultural em que estão inseridos. Como asseveram Mondada; Dubois (2003, p. 21): 
Esta abordagem implica uma visão dinâmica que leva em conta não somente o sujeito "encarnado", mas ainda um sujeito sócio-cognitivo mediante uma relação indireta entre os discursos e o mundo. Este sujeito constrói o mundo ao curso do cumprimento de suas atividades sociais [...].

Essa abordagem é caracterizada por marcar os processos que envolvem a referenciação pelo meio sociocognitivo, que demonstra a dinamicidade desses processos. Neste trabalho, preocupamo-nos com a importância dessa característica para o ensino das formas dêiticas pronominais já sentida por Cavalcante; Custódio Filho; Brito (2014), como podemos constatar em suas palavras:

\begin{abstract}
A natureza sociocognitva da referenciação garante o caráter marcadamente dinâmico do processo. Esse dinamismo deve ser trabalhado pedagogicamente, de modo que os alunos sejam estimulados a produzir e ler os textos atentando para as operações cognitivas que regulam tal processo. Uma vez que percebam que qualquer texto é naturalmente incompleto, eles poderão usar isso a seu favor, empregando mecanismos que possibilitem a recuperação de informações implícitas. Isso implica trazer para a sala de aula uma prática que considere a importância dos conhecimentos prévios para o uso linguístico $(2014$, p.41).
\end{abstract}

Dentre os elementos de referenciação utilizados nessa re-contrução do mundo a que os sujeitos fazem uso, destacam-se os elementos referenciais dêiticos, que são elementos referenciais que recuperam informações do enunciado, em um plano extralinguístico; segundo Ciulla (2008, p. 56), dêiticos caracterizam-se por dois traços específicos:

1) Os dêiticos são indicadores de ostensão, isto é, indicam os limites do objeto referido no tempo e no espaço, tomando como base o posicionamento do falante no momento do ato comunicativo; e 2) também apresentam uma condição de subjetividade, que é manifestada pelo vínculo entre os participantes do discurso e a situação enunciativa.

Assim, como referido pela autora, esses elementos mantêm estreita relação com os aspectos enunciativos, mencionados pelas abordagens citadas, pois são construídos a partir da posição dos sujeitos envolvidos no momento da comunicação, bem como esses mecanismos participam do processo de interação desses indivíduos com o mundo, a cultura e a sociedade em que estão inseridos.

A marca de ostensividade mencionada por Ciulla (2008) já fora observada por Lyons ([1995], 1997) como uma característica que coloca os elementos dêiticos em uma fronteira delicada: entre o contexto da enunciação e as marcas não verbais, expressas na oralidade. $\mathrm{O}$ autor define a ostensão como: “[...] A referência não verbal, gestual, destinada a cumprir uma função essencial na definição das expressões linguísticas que, quando têm êxito, assim são compreendidas " (LYONS, [1995], 1997, p.328, tradução nossa).

Os mecanismos dêiticos têm, portanto, estreita dependência com aspectos extralinguísticos, bem como, com a esfera social, tão cara para os pesquisadores mencionados, pois os elementos dêiticos como podemos observar estão diretamente relacionados com o processo enunciativo e têm por base o posicionamento dos sujeitos, que estão inseridos nesse processo; qualquer falha na localização dos elementos ou na identificação da subjetividade, marcada por esses mecanismos, pode ocasionar uma interpretação duvidosa. Para melhor compreensão de como esse processo ocorre em nossas práticas com a linguagem apresentamos, mais detalhadamente, esse

5 “[...] la referencia no verbal, gestual, destinada al cumplimento de uma función esencial em la definición de las expresiones linguísticas, y, cuando tiene êxito, entendida así”. 
processo de referenciação no tópico seguinte.

\section{Processos de referenciação: a dêixis}

Entre os processos mais utilizados para a construção e reconstrução textual estão as anáforas e os dêiticos; para este trabalho, nosso interesse será focado no uso de dêiticos, por isso apresentaremos abaixo alguns dos dêiticos mais usuais. A apresentação desses processos se dará apenas para melhor definição dos processos escolhidos para serem analisados neste artigo.

O processo em que aparecem elementos dêiticos depende, exclusivamente, dos enunciatários dos discursos. Segundo Apothéloz (2003, p.66), "As expressões linguísticas cuja interpretação se apoia nos parâmetros de lugar, tempo e pessoa da situação de enunciação são chamadas de dêiticas".

Dessa forma, a relação dos elementos dêiticos deve submissão ao contexto "espácio-temporal" mantido pelo ato da enunciação. Outra peculiaridade desses elementos é o objetivo que eles têm em deslocar o campo de atenção dos interlocutores para um referente, característica apontada por Bosh (1983 apud APOTHÉLOZ, 2003, p.68), como uma das principais diferenças entre dêixis e anáfora. Enquanto esta mantém a atenção sobre um referente, aquele desloca o campo da atenção para o referente.

Essa característica marca, segundo Bürhler (1982), as coordenadas discursivas nas quais os interlocutores se baseiam para guiarem sua enunciação. Por isso, para o autor, essa característica dos dêiticos é a sua principal diferença em relação a outros processos referenciais, como a anáfora. Para Leal (2015, p.78), "é a partir das coordenadas indicadas pelos processos dêiticos que o significado dessas formas será orientado para um campo de significação”.

Outra importante distinção dos elementos dêiticos em relação aos elementos anafóricos encontra respaldo nos trabalhos de Lyons (1977), para quem a marca principal dos mecanismos dêiticos é a relação destes com momentos da enunciação, sobretudo, com as noções de pessoa, espaço e tempo. Para o autor, a coordenada básica na qual os falantes se baseiam, no momento da enunciação, está na indicação da pessoa em que o discurso acontece, essa é, para ele, o "ponto-zero" da enunciação.

Lyons (1977) retoma a noção de coordenadas mencionadas por Bürhler (1982) e destaca as noções de pessoa, espaço e tempo como marcos para ocorrer a localização dos falantes nos processos de referenciação, durante a enunciação. O ponto de vista de Lyons (1977) é especialmente importante para nossa pesquisa, pois, como será expresso no próximo tópico, partimos do pressuposto de que essas noções dispostas por Lyons são as marcas principais e essenciais a todos os tipos de dêiticos. O teórico apresenta seu conceito, portanto, de dêiticos como um termo que define:

[...] A identificação do referente por meio de algum gesto corporal pelo falante. ('Dêixis' significa indicar ou mostrar em grego; 'index' é a palavra latina para o dedo indicador, como a espanhola 'indice'. A identificação mediante um gesto corporal, que pode ter origem natural, biológica, institucionalizada com esta função em muitas culturas). Qualquer expressão referencial que tenha as mesmas propriedades lógicas que um gesto corporal será dêitica por este motivo ${ }^{6}$ (LYONS, [1995], 1997, p. 329,

$6 \quad$ [...] la identificatión del referente por Médio de algún gesto corporal por parte del hablante. ('Deixis'significa indicar o mostrar em griego; 'index' es la palabra latina para el dedo señalador, igual que la española 'índice'. La indentificación mediante um gesto corporal, que pude tener um origen natural, biológico, institucionalizado com 
grifos do autor, tradução nossa).

Dessa forma, acreditamos que independentemente das diferenças entre os elementos dêiticos, todas as espécies desses mecanismos manterão essas características, que orientam o discurso dos falantes e, obviamente, a instância da enunciação. Ressaltamos, ainda, o caráter indicial dos termos dêiticos, destacados por Lyons ([1995], 1997), cuja marca é fundamental para indicar as pessoas, o tempo e o espaço em que ocorre a enunciação.

Esses três sinais denotam os tipos de dêiticos mais comuns no discurso: pessoal, temporal e discursivo. No entanto, posteriormente aos estudos de Lyons (1977), Fillmore (1982) expande as pesquisas sobre dêiticos e discrimina mais duas espécies de dêiticos - dêiticos sociais e discursivos, que, para ele, são tipos de dêiticos secundários aos apresentados por Lyons.

Fillmore ([1984], 1997 apud LEAL, 2015, p.85) apresenta os dêiticos como formas de enunciados "que são determinadas por certos aspectos do ato da comunicação em que as declarações em questão podem desempenhar um papel e que são interpretadas pelo conhecimento". O autor acredita que as características essenciais desses elementos estão resguardadas pelas funções eminentemente enunciativas que eles exercem no discurso.

Por isso, ele não altera as marcas de pessoa, tempo e espaço mencionadas por Benveniste (1976) e por Lyons ([1995], 1997), para este, consideradas coordenadas a serem seguidas pelos interlocutores do discurso. Mantendo essas relações, Fillmore ([1984], 1997 apud LEAL, 2015, p.85) define esses mecanismos dêiticos da seguinte forma: “(1) a identidade dos interlocutores em uma situação de comunicação, denominada pelo termo dêixis de pessoa; (2) o lugar ou lugares em que esses indivíduos estão localizados, para o qual temos o tempo dêixis de lugar; (3) o tempo em que o ato de comunicação toma lugar (...)".

Como mencionamos, Fillmore ([1984], 1997) apresenta mais dois tipos de dêiticos, os sociais e os discursivos. Para o autor esses mecanismos se distinguiriam dos demais por terem maior ênfase no traço da subjetividade. Sobretudo, os dêiticos sociais que marcariam as escolhas dos interlocutores frente ao jogo do processo enunciativo.

Os elementos que indicariam "partes difusas do discurso" (CAVALCANTE, 2000, p. 49) seriam os dêiticos discursivos ou textuais, como mais tarde a literatura linguística passou a denominá-los. Fillmore ([1984], 1997) cria essa nova nomenclatura para marcar a diferença entre esses elementos e as anáforas; atualmente, Cavalcante; Custódio Filho; Brito (2014, p.94) consideram que os elementos nomeados como dêiticos textuais sempre ocorrem em um processo de hibridismo, "que mistura uma função anafórica (ou de introdução referencial) com uma função dêitica. É dêitico porque considera o ponto de origem do locutor; é anafórico (ou introdutório) porque sempre vai estabelecer uma cadeia com outro referente do texto".

Seguindo com essas considerações acerca dos elementos dêiticos, Sousa (2005) apresenta um breve resumo, citando Castro (2010), em que destaca os elementos dêiticos que marcam a pessoa, o tempo e o espaço do discurso. Transcrevemos, a seguir, essas considerações por considerarmos que, como Lyons, essas marcas são coordenadas da instância da enunciação:

esta función em muchas culturas). Cualquier expresión referencial que tenga lãs mismas propriedades lógicas que um gesto corporal será deíctica por este motivo. 
a) Dêixis Pessoal: esse tipo de dêitico, segundo Castro (2010), trata especificamente da inscrição do sujeito no ato comunicativo. Para o autor, os dêiticos pessoais tratam diretamente da codificação do papel dos participantes no evento de fala, no momento da enunciação [...] Dêixis Textual: De acordo com Apothéloz (2003), esse mecanismo designa o emprego de determinadas expressões que tem o objetivo de se referir a segmentos, a lugares ou a momentos do próprio texto em que essas expressões são utilizadas [...] (CASTRO, 2010, apud, SOUSA, 2005, p.113).

A seguir apresentamos como essas relações são apreendidas nos materiais didáticos selecionados e como as atividades de análise linguística podem colaborar para a construção de uma aprendizado coerente com a abordagem sociocognitivo-discursiva.

\section{Atividades de análise linguística: como os livros didáticos tratam o fenômeno dêitico}

Nesta pesquisa, nos propusemos a analisar cinco manuais didáticos, como mencionados anteriormente. Nesta seção, apresentamos nossas considerações acerca da análise realizada nessas coleções, expomos nosso julgamento realizado a partir dos objetivos e das hipóteses que nos levam a afirmar a importância desta investigação para a linguística e para o meio escolar, pois compreender como ocorrem as relações cognitivas e sociais que envolvem o fenômeno da dêixis é fundamental para leitores e escritores proficientes, o que é indispensável para alunos do nível médio, para quem se destinam as coleções analisadas.

O seguinte quadro expõe uma síntese do nosso estudo, em que as atividades de análise linguística (indicadas nas linhas do quadro) foram avaliadas conforme os critérios de análise (indicados nas colunas do quadro):

\begin{tabular}{|l|l|l|l|l|l|}
\hline \multicolumn{2}{|l|}{ Atividade } & $\begin{array}{l}\text { Critério } \\
\text { de ordem } \\
\text { prática }\end{array}$ & $\begin{array}{l}\text { Crité- } \\
\text { rio de } \\
\text { ordem } \\
\text { cogni- } \\
\text { tiva }\end{array}$ & $\begin{array}{l}\text { Crité- } \\
\text { rio_de } \\
\text { ordem } \\
\text { cultu - } \\
\text { ral }\end{array}$ & $\begin{array}{l}\text { Crité- } \\
\text { rio de } \\
\text { ordem } \\
\text { norma- } \\
\text { tiva }\end{array}$ \\
\hline 1 & COLEÇÃO1_B1 & $\mathrm{X}$ & $\mathrm{X}$ & $\mathrm{X}$ & 0 \\
\hline 2 & COLEÇÃO1_B2 & $\mathrm{X}$ & $\mathrm{X}$ & $\mathrm{X}$ & 0 \\
\hline 3 & COLEÇÃO1_B3 & $\mathrm{X}$ & $\mathrm{X}$ & $\mathrm{X}$ & 0 \\
\hline 4 & COLEÇÃO1_B4 & $\mathrm{X}$ & 0 & $\mathrm{X}$ & $\mathrm{X}$ \\
\hline 5 & COLEÇÃO1_B5 & $\mathrm{X}$ & $\mathrm{X}$ & 0 & $\mathrm{X}$ \\
\hline 6 & $\begin{array}{l}\text { COLEÇÃO_2 } \\
\text { B6 }\end{array}$ & $\mathrm{X}$ & $\mathrm{X}$ & $\mathrm{X}$ & $\mathrm{X}$ \\
\hline 7 & $\begin{array}{l}\text { COLEÇÃO 2 } \\
\text { _B7 }\end{array}$ & 0 & $\mathrm{X}$ & $\mathrm{X}$ & $\mathrm{X}$ \\
\hline 8 & COLEÇÃO 2_B8 & $\mathrm{X}$ & $\mathrm{X}$ & $\mathrm{X}$ & $\mathrm{X}$ \\
\hline
\end{tabular}




\begin{tabular}{|c|c|c|c|c|c|c|}
\hline 9 & $\begin{array}{l}\text { COLEÇÃO } \\
\text { _B9 }\end{array}$ & 2 & X & X & $\mathrm{X}$ & 0 \\
\hline 10 & $\begin{array}{l}\text { COLEÇÃO } \\
\text { B10 }\end{array}$ & & X & $X$ & 0 & 0 \\
\hline 11 & $\begin{array}{l}\text { COLEÇÃO } \\
\text { B11 }\end{array}$ & $2_{-}$ & X & 0 & 0 & $X$ \\
\hline 12 & $\begin{array}{l}\text { COLEÇÃO } \\
\text { B12 }\end{array}$ & $2_{-}$ & X & $X$ & 0 & $X$ \\
\hline 13 & $\begin{array}{l}\text { COLEÇÃO } \\
\text { B13 }\end{array}$ & $3_{-}$ & X & 0 & 0 & $X$ \\
\hline 14 & $\begin{array}{l}\text { COLEÇÃO } \\
\text { B14 }\end{array}$ & 3 & $X$ & $X$ & $X$ & $X$ \\
\hline 15 & $\begin{array}{l}\text { COLEÇÃO } \\
\text { B15 }\end{array}$ & 3 & X & 0 & $X$ & $X$ \\
\hline 16 & $\begin{array}{l}\text { COLEÇÃO } \\
\text { B16 }\end{array}$ & 3 & X & $X$ & $X$ & $X$ \\
\hline 17 & $\begin{array}{l}\text { COLEÇÃO } \\
\text { B17 }\end{array}$ & 3 & X & $X$ & $X$ & $X$ \\
\hline 18 & $\begin{array}{l}\text { COLEÇÃO } \\
\text { B18 }\end{array}$ & $3_{-}$ & X & 0 & 0 & $X$ \\
\hline 19 & $\begin{array}{l}\text { COLEÇÃO } \\
\text { B19 }\end{array}$ & 3 & $X$ & 0 & 0 & $X$ \\
\hline 20 & $\begin{array}{l}\text { COLEÇÃO } \\
\text { B20 }\end{array}$ & $3_{-}$ & $X$ & $X$ & $X$ & $X$ \\
\hline 21 & $\begin{array}{l}\text { COLEÇÃO } \\
\text { A21 }\end{array}$ & 4 & X & $X$ & $X$ & 0 \\
\hline 22 & $\begin{array}{l}\text { COLEÇÃO } \\
\text { A22 }\end{array}$ & 4 & X & $X$ & $X$ & 0 \\
\hline 23 & $\begin{array}{l}\text { COLEÇÃO } \\
\text { B23 }\end{array}$ & 4 & 0 & $X$ & $X$ & 0 \\
\hline 24 & $\begin{array}{l}\text { COLEÇÃO } \\
\text { B24 }\end{array}$ & $4_{-}$ & $X$ & $X$ & $X$ & $X$ \\
\hline 25 & $\begin{array}{l}\text { COLEÇÃO } \\
\text { B25 }\end{array}$ & 4 & $X$ & $X$ & $X$ & 0 \\
\hline 26 & $\begin{array}{l}\text { COLEÇÃO } \\
\text { B26 }\end{array}$ & 4 & $X$ & $X$ & $X$ & $X$ \\
\hline
\end{tabular}




\begin{tabular}{|l|l|l|l|l|l|}
\hline 27 & $\begin{array}{l}\text { COLEÇÃO 5_ } \\
\text { B27 }\end{array}$ & $\mathrm{X}$ & 0 & 0 & $\mathrm{X}$ \\
\hline 28 & $\begin{array}{l}\text { COLEÇÃO 5 } \\
\text { B28 }\end{array}$ & 0 & 0 & 0 & $\mathrm{X}$ \\
\hline 29 & $\begin{array}{l}\text { COLEÇÃO 5 } \\
\text { B29 }\end{array}$ & 0 & 0 & 0 & $\mathrm{X}$ \\
\hline
\end{tabular}

Quadro 1: Síntese das análises. Fonte: LEMOS, 2016, p.66.

Para compreensão desse quadro, devemos considerar que as atividades, numeradas de 1 a 29, apresentadas nas linhas do quadro, são identificadas por um código e foram analisadas de acordo com os critérios ${ }^{7}$ destacados nas colunas. Por exemplo: a letra $\mathrm{X}$, nas linhas que identificam as atividades, significa que a atividade apresentou o critério correspondente ao que está indicado na coluna. O numeral 0 , na linha, indica que o critério da coluna correspondente não foi encontrado na atividade analisada.

Através do quadro, podemos observar que algumas coleções apresentam maior número de atividades que tratam dos pronomes pessoais e de tratamento, apesar disso, nem todas as coleções, em suas atividades, aborda a reflexão no uso da função dêitica desses pronomes, característica do critério de ordem cognitiva.

Outra conclusão que se pode chegar após a leitura do quadro é que os critérios de análise não são estanques nas atividades, ou seja, as atividades mesclam seus objetivos, em sua maioria, com mais de dois critérios, o que nos possibilitou concluir que as atividades buscavam relacionar outros aspectos das funções dêiticas, oferecendo a possibilidade de alunos e professores refletirem sobre a função dos mecanismos dêiticos em diferentes contextos, não apenas em contextos formais. Ainda assim, encontramos exemplares que privilegiaram o caráter meramente gramatical dos pronomes, desconsiderando suas funções sociocognitivo-discursivas.

Apresentamos nossos resultados através dos critérios de análise que compõem as colunas do quadro referido. Dessa forma, pretendemos demonstrar como cada critério pode contribuir para a compreensão dos elementos dêiticos e de suas funções intersubjetivas, que apontam os participantes do discurso e contribuem para a construção dos sentidos dos textos.

Analisamos cada critério, segundo os objetivos de Campos (2014), em todas as atividades de todas as coleções selecionadas e apresentamos os exemplos com os resultados mais substanciais da proposta didática de cada livro, conforme as seguintes coleções:

1. ABAURRE, M.L.M; ABAURRE.M,B,M; PONTARA, M. Português: contexto, interlocução e sentido.1.ed. São Paulo: Moderna, 2008.

2. AMARAL, E; FERREIRA, M.; LEITE, R.; ANTÔNIO, S. Língua portuguesa: novas palavras. 1.ed. São Paulo: FTD, 2010.

3. CEREJA, W.R; MAGALHÃES, T.C. Português linguagens: literatura, produção de texto e gramática. 7.ed. São Paulo: Saraiva, 2010.

7 Referimo-nos aos critérios utilizados na análise do corpus deste artigo, os quais foram definidos por Campos (2014) como faculdades para análise de atividades de análise linguística. 
4. BARRETO, R.G. (Org.). Português: Ser protagonista. 1.ed. São Paulo: edições SM, 2010.

5. TORRALVO, F.I; MINCHILLO, C.C. Linguagem em movimento. São Paulo: FTD, 2010 .

\section{Critério de análise: Ordem prática}

Campos (2014) define o critério de ordem prática como um objetivo que deve orientar as atividades de análise linguística visando à reflexão e à capacidade do aluno de produzir e interpretar textos orais e escritos, de modo a levá-lo a compreender os mais diversos usos dos elementos gramaticais no funcionamento da linguagem.

Relacionamos esse critério com a proposta de Cavalcante, Custódio-Filho; Brito (2014, p. 85) que definem os elementos dêiticos a partir do "vínculo entre o contexto e a situação enunciativa". Além disso, esse critério coaduna-se com a noção de competência comunicativa adotada por este trabalho, uma vez que, para Habermas (1989), a competência dos falantes é construída por processos intersubjetivos, como os estabelecidos pelos mecanismos dêiticos. Acreditamos que há uma relação entre a dependência dos elementos dêiticos com a situação enunciativa e o critério de ordem prática, que estabelece uma ligação entre a compreensão dos elementos gramaticais e o contexto em que são utilizados.

Em nossa análise, encontramos atividades cujos autores utilizaram esse critério para apresentar as funções dos mecanismos dêiticos pronominais pesquisados (pronomes pessoal e de tratamento). Das vinte e nove atividades avaliadas, apenas quatro não enfatizam esse aspecto. Ainda assim, podemos observar que algumas atividades utilizam o critério de ordem prática de forma criativa, produtiva, com o propósito de inserir o aspecto gramatical das formas dêiticas.

Acreditamos que os autores das coleções reconhecem que é necessário apreender o contexto e desenvolver a competência comunicativa dos alunos para identificar as diversas funções dos mecanismos dêiticos, sem descuidar do ensino da norma gramatical, permitindo que os estudantes tenham acesso a outras funções dos elementos dêiticos, não apenas o aspecto normativo, que poderia prevalecer em alguns itens da atividade. Louvamos essa iniciativa dos autores, pois não defendemos o aprendizado das funções dêiticas isolado do conhecimento pragmático que esses elementos suscitam.

Para demonstrar o que observamos e constatamos no material analisado, selecionamos 3 (três) atividades que ilustram cada um dos critérios de análise definidos para a pesquisa e que representam o todo observado.

O exemplo a seguir é uma atividade retirada do volume dois da coleção Português: contexto, interlocução e sentido. Essa coleção foi catalogada em nosso corpus como coleção 1, a atividade a que nos referimos é indicada para alunos do segundo ano do Ensino Médio e aborda o assunto variação linguística. Para isso, utiliza as diversas formas de uso do pronome pessoal, a fim de refletir sobre os contextos em que essas formas podem ser utilizadas. Em pelo menos um item da atividade é possível notar a evidência dada para o fato de que este é apenas uma das prováveis variações que a língua portuguesa sofre.

A atividade pretende se desenvolver em um contexto de uso da língua, para isso emprega um gênero muito comum no cotidiano dos falantes: o anúncio publicitário. Isso nos leva a inferir 
que a intenção dos autores do livro é desenvolver a competência comunicativa dos alunos através de um gênero conhecido por eles e reconhecido como uma prática sociocultural, nesse caso, representado pelo gênero anúncio. Essa característica da atividade é estabelecida com base nos pressupostos dos PCNs de língua portuguesa, que orientam as atividades de reflexão linguística e indicam que elas estejam embasadas e contextualizadas com gêneros acessíveis ao público ao qual se destina (BRASIL, 2000, p.15).

A questão visa a alertar os alunos sobre a utilização do pronome pessoal de terceira pessoa e a adequação das formas reta e oblíqua, que podemos observar já no item a da proposta, o que nos leva a inferir que o objetivo da atividade é marcar os contextos nos quais as formas pronominais tônicas e átonas ocorrem, segundo a gramática normativa. Observemos a atividade retirada do LD em questão:

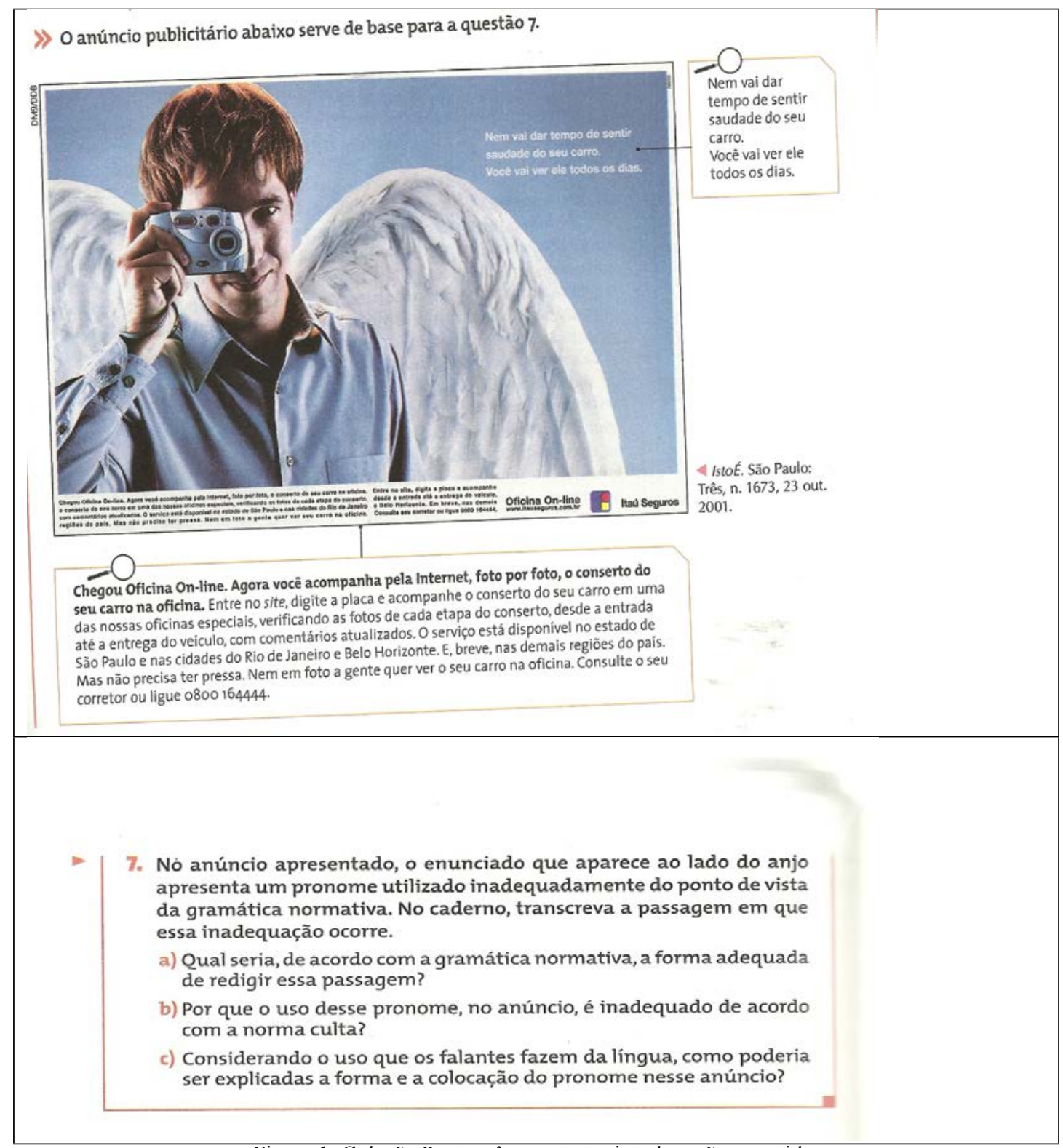

Figura 1: Coleção Português: contexto, interlocução e sentido.

Julgamos que essa atividade utiliza o critério de ordem prática, mencionado por Campos (2014), dado que, para a autora, o critério de ordem prática enfatiza os diferentes contextos em que podemos utilizar as modalidades de uso oral e escrita, cuja reflexão parece ser o foco da questão, já 
que somente o item c demonstra outra preocupação de ordem gramatical, que se relaciona com a função do pronome pessoal ele em diferentes contextos sociodiscursivos.

Com relação às características dêiticas, observamos que é mencionada apenas nos dois últimos itens uma preocupação com os falantes e suas posições na cena enunciativa, assim enfatizando as "instâncias produtoras do discurso" (SAMPAIO, 2010, p.1338) característica dos aspectos metadiscursivos dos pronomes dêiticos observados.

\section{Critério de análise: ordem cognitiva}

Segundo Campos (2014), o critério de ordem cognitiva visa gerar nos alunos o interesse na habilidade de refletir sobre as formas linguísticas. No tocante ao conhecimento sobre as formas pronominais dêiticas, o critério de ordem cognitiva busca desenvolver o pensamento reflexivo dos alunos sobre os processos de construção de sentido desses mecanismos dêiticos pronominais. Apenas duas atividades da primeira série do Ensino Médio desenvolveram o critério de ordem cognitiva, enquanto vinte atividades da segunda etapa do Ensino Médio articularam o critério de ordem cognitiva com o ensino dos elementos pronominais dêiticos, totalizando vinte e duas atividades que abordaram esse critério.

Com relação a este critério encontramos duas atividades nos livros da $1^{\text {a }}$ série do Ensino Médio, aliás, que apresentaram exemplares de atividades, direcionadas para o critério de ordem cognitiva, ainda que totalizem apenas duas atividades, julgamos que houve uma preocupação dos autores da coleção para com a primeira etapa do Ensino Médio.

Outro aspecto que avaliamos como pertinente nas atividades que utilizamos para exemplificar nossa análise desse critério está no conteúdo das atividades, que sempre estavam contextualizadas com algum gênero do repertório de conhecimento do público a que se direciona a coleção. Textos de canções, tirinhas e notícias serviam de apoio para exemplificar as relações de sentido, que são construídas com as estruturas referenciais dêiticas.

Como exemplo dessa postura adotada pelos autores da coleção, está a atividade a seguir (figura 2), que aborda as funções dos dêiticos pronominais em contextos que envolvem a oralidade e a escrita, destacando o caráter de ordem cognitiva, defendido por Campos (2014). Além disso, os outros critérios defendidos pela autora são abordados na atividade, pois a questão intenta desenvolver a prática e a reflexão sobre o sentido da forma pronominal dêitica destacada. Insistimos que os critérios devem e podem ser utilizados de forma articulada, visando sempre o sucesso no aprendizado; a atividade seguinte exemplifica bem essa articulação entre os critérios, vejamos: 
2. Leia o trecho de um artigo de revista dirigida ao público feminino adolescente.

Sobre petecas caindo. Pegue a sua e volte para o jogo!

Foi por isso que respondi ao meu amigo que ele, no mínimo, não estava sabendo as regras do jogo. Como assim, não pode deixar a peteca cair? Ela cai mesmo. E a gente pega. $\mathrm{E}$ adivinha? Cai de novo, pegamos de novo e... enfim. $O$ ponto é: não dá para manter $O$ ritmo o tempo inteiro. Nem na quadra, nem Prata, Liliane. Capricho. Sâo Paulo: Abril, 27 abr. 2008. p. 106.

em lugar nenhum, por mais que a gente se esforce. [...]

Mesmo que esteja dando seu melhor em alguma coisa, saiba que seu melhor inclui momentos não tão bons. [...] vai ser muito mais produtivo e bacana com você mesma aceitar esses períodos e, só então, retomar o fôlego.

\section{W}

a) "Deixar a peteca cair" e "voltar para o jogo" têm no texto sentido metafórico. Explique.

b) A que pessoa discursiva se refere a locução "a gente", na quarta linha? 0 que explica o emprego do verbo pegar em duas formas distintas, logo na sequência?

c) A expressão "a gente" é muito comum na fala, principalmente em situações informais. Como se explica seu emprego em um texto publicado em uma revista impressa?

d) Que formas pronominais se referem ao leitor do texto? Com que finalidade, provavelmente, a autora as empregou?

Figura 2: Coleção Português: ser protagonista.

No tocante ao critério de ordem cognitiva, Campos (2014) afirma que esse aspecto busca a reflexão, por parte dos alunos, sobre a função das formas gramaticais em um texto. Na atividade constante da figura 2, essa reflexão é integrada com a procura pela compreensão das formas dêiticas em seus contextos de uso. Percebemos isso melhor no item $\mathbf{d}$ da atividade, que intenta provocar os alunos no sentido de compreender o aspecto metadiscursivo, apontando para as instâncias produtoras do discurso, das formas dêiticas pronominais.

O aspecto normativo está contemplado na atividade, no item $\mathbf{b}$, que busca relacionar o emprego da forma a gente, mais informal, e da forma nós, variedade padrão do dêitico pessoal. Julgamos pertinente a reflexão proposta pelos autores da coleção, uma vez que essa discussão articula os valores sociocognitivo-discursivos, defendidos por esta pesquisa, como também associa esses valores ao sentido gramatical, que essas formas adquirem em seus contextos de uso. Além disso, observamos que o autor busca refletir sobre a função metadiscursiva da forma a gente que indica uma orientação para o contexto de uso da expressão.

Consideramos essas correlações de abordagens pertinentes para o ensino e para a formação de leitores e escritores proficientes, que conhecem não apenas os valores gramaticais das formas pronominais, como também os valores sociocognitivo-discursivos, inerentes a essas formas, bem como destacar aspectos referentes às funções metadiscursivas desses elementos colaboram com o processo de reflexão inerente ao critério de ordem cognitiva. A junção desses aspectos colabora para a construção da competência comunicativa dos alunos, que é pautada por um processo de intersujetividade nem sempre percebido no ato enunciativo, por isso a importância desse tipo de atividade.

A articulação de outros aspectos, como os normativos e os cognitivos, pode garantir não apenas uma boa formação linguística para os alunos do Ensino Médio, como também está relacionada com a noção de competência comunicativa defendida por nós, pois segundo Habermas (1989), é, a partir da compreensão de mundo, que o homem apropria-se da linguagem e de suas funções. Nas palavras do autor: "A suposição do mundo não é uma ideia regulativa, mas 'constitutiva' para a referência de tudo a respeito do qual podem ser verificados fatos" (HEBERMAS, 1989, p.39). Consoante a esse pensamento, Vygotsky (1989, p. 87) afirma que: "A gramática e a escrita ajudam a criança a passar para um nível mais elevado do desenvolvimento". 
As afirmações dos teóricos ratificam nossa suposição de que as atividades que apresentam uma boa articulação entre os aspectos sociocognitivo-discursivos, neste trabalho indicados pelos critérios de análise de Campos (2014), e as funções normativas dos elementos pronominais dêiticos, defendidos pelos PCNs, são atividades mais ricas na exploração das diversas funções desses mecanismos dêiticos.

Dessa forma, as atividades dessa coleção analisadas articulam os aspectos mencionados por Campos (2014) e buscam construir um pensamento reflexivo nos alunos, através da defesa de pressupostos que são contemplados nos PCNs e da construção da competência comunicativa dos alunos, por meio de suas práticas de linguagem.

\section{Critério de análise: ordem cultural}

Segundo Campos (2014), o critério de ordem cultural é um elemento essencial na composição de atividades que objetivam ensinar o funcionamento das estruturas da língua natural de um falante, pois, para a autora, só é possível o aluno compreender o sentido e a função de estruturas linguísticas, a partir da percepção de que a língua é um elemento formador da identidade cultural, uma vez que o sentido e a função das estruturas linguísticas têm estreita relação com a cultura de uma sociedade.

No caso dos elementos dêiticos, esse aspecto torna-se ainda mais forte, uma vez que o sentido desses mecanismos é construído nas práticas enunciativas da linguagem, assim, consideramos muito importante que os alunos do Ensino Médio possam refletir sobre o critério cultural como elemento constituinte do sentido dos elementos dêiticos pronominais.

O fato de os autores integrarem apenas dois dos critérios definidos por Campos (2014) revela certo descaso com a inter-relação entre os critérios. Além do mais, deixaram de fora o critério de ordem cultural, que foi desprezado quase que totalmente na coleção Língua Portuguesa: Novas Palavras, falha que consideramos grave e, ao mesmo tempo, revela uma incoerência de abordagem teórica, que justamente o aspecto cultural tenha sido ignorado na coleção, uma vez que, segundo Xavier (1998,p.68), "Não há possibilidade de se desprezar o valor do componente cultural na educação de um indivíduo [...]".

Observamos que o texto foi utilizado como um pretexto para a realização da atividade com os pronomes, já que não foi explorado, com propriedade, o caráter interpretativo ou reflexivo sobre ele; com relação à análise da função dêitica das estruturas pronominais, julgamos que houve uma tentativa de demonstrar a função ostensiva desses mecanismos no item a da questão, pois intenta-se indicar o eu lírico do poema através do reconhecimento dessa função dêitica - o item pede para o aluno julgar verdadeira ou falsa a afirmativa que atesta que na forma nos há uma relação entre o interlocutor e o eu lírico do poema, bem como a forma pronominal te, que se relaciona apenas com o interlocutor.

Notamos que esse item leva o aluno a refletir sobre as relações enunciativas exercidas pelas formas pronominais destacadas no poema, já que para marcar o item como verdadeiro ou falso o aluno terá que buscar no texto as relações referenciais que existem entre o eu lírico, o enunciador, e as formas nos e te.

No entanto, a busca da reflexão dessa característica dos dêiticos ocorre de forma subentendida, o que nos leva a inferir que os autores da coleção poderiam ter desenvolvido essa reflexão com 
os outros itens, dado que os demais fazem referência a outras formas de dêiticos e, ainda assim, destacam mais características formais das estruturas que aspectos funcionais, como o item e: "Em 'e já o sabíamos', o demonstrativo o equivale a uma oração implícita no cotexto: E já sabíamos que a jaula (a Terra) era azul", por exemplo.

A própria nomenclatura utilizada pela atividade indica uma preocupação maior com aspectos ligados à gramática normativa da língua portuguesa, o que observamos no item a, em que se pretende desenvolver a orientação do eu lírico do poema. Com isso, acreditamos que o critério de ordem cultural foi deixado de lado, pois aspectos relacionados à postura dos interlocutores assumida no poema poderiam ser explicados conforme as escolhas dos interlocutores, que são orientadas por práticas culturalmente estabelecidas.

Percebemos, ainda, que a questão privilegiou o reconhecimento de estruturas que atuam na gramática normativa da língua, ao mencionar termos e funções próprias da estrutura interna da língua portuguesa, como no item e, mencionar uma suposta oração implícita pelo pronome oblíquo o. No entanto, deixa à margem a reflexão desses elementos em sua função dêitica, não mencionando de forma mais clara as relações cognitivas existentes na utilização desses mecanismos dêiticos. Além disso, não há menção, quanto aos motivos que levam o aluno a julgar o item a o correto. Essa explicação poderia ser realizada com a aplicação do critério de ordem cultural, que poderia ser utilizado para indicar as práticas culturais que admitimos atualmente em nossa língua.

Logo, concluímos que essa atividade destaca o aspecto gramatical e não desenvolve de forma mais ampla a competência comunicativa do público a quem se destina, pois não articula os critérios de ordem prática, cultural e cognitiva com o aspecto normativo, enfatizado pela questão. Por outro lado, a mesma coleção apresenta duas atividades em que há articulação dos critérios estabelecidos com a abordagem sociocognitivo-discursiva, em que os autores propõem atividades que favorecem o desenvolvimento da competência comunicativa, através do exercício.

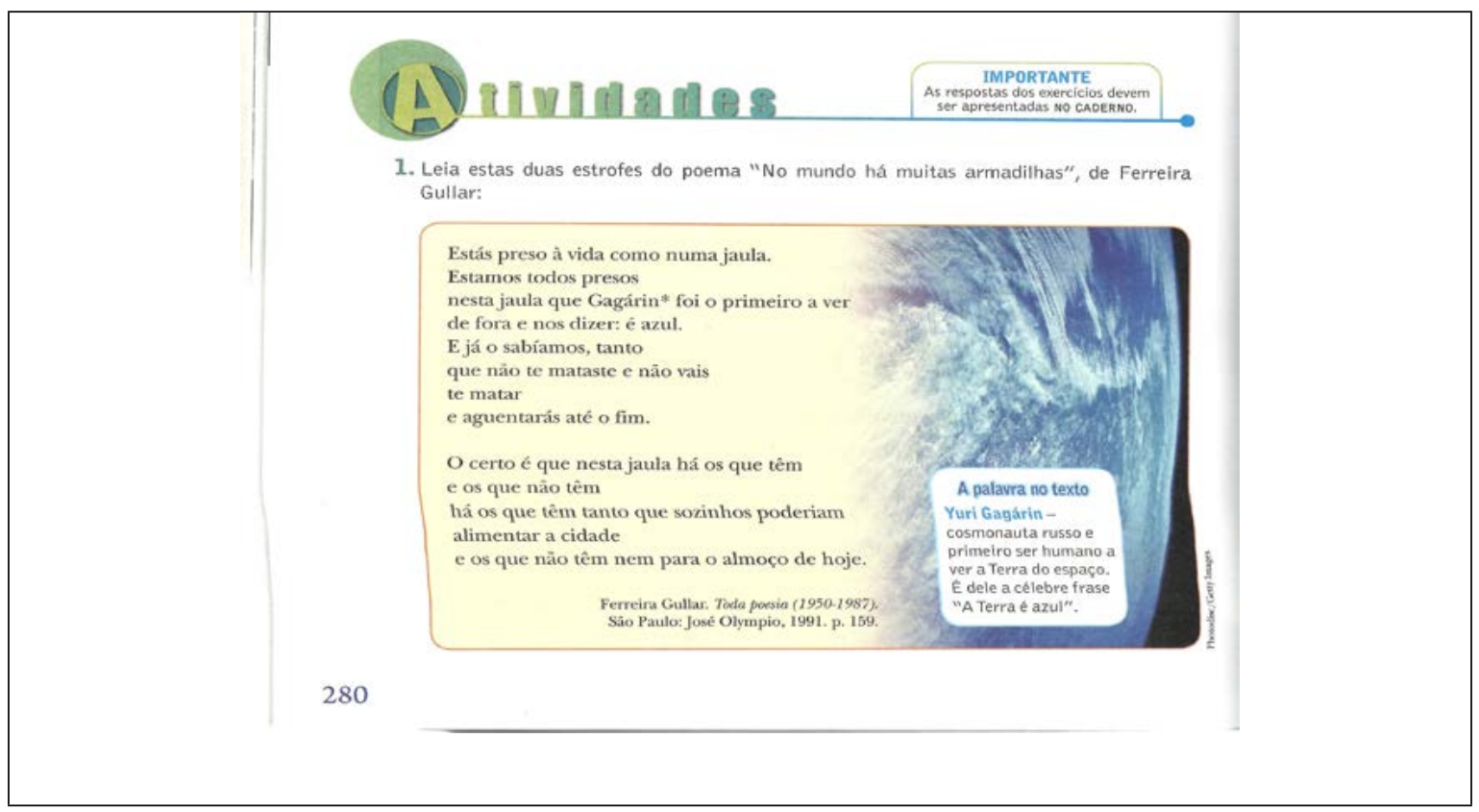




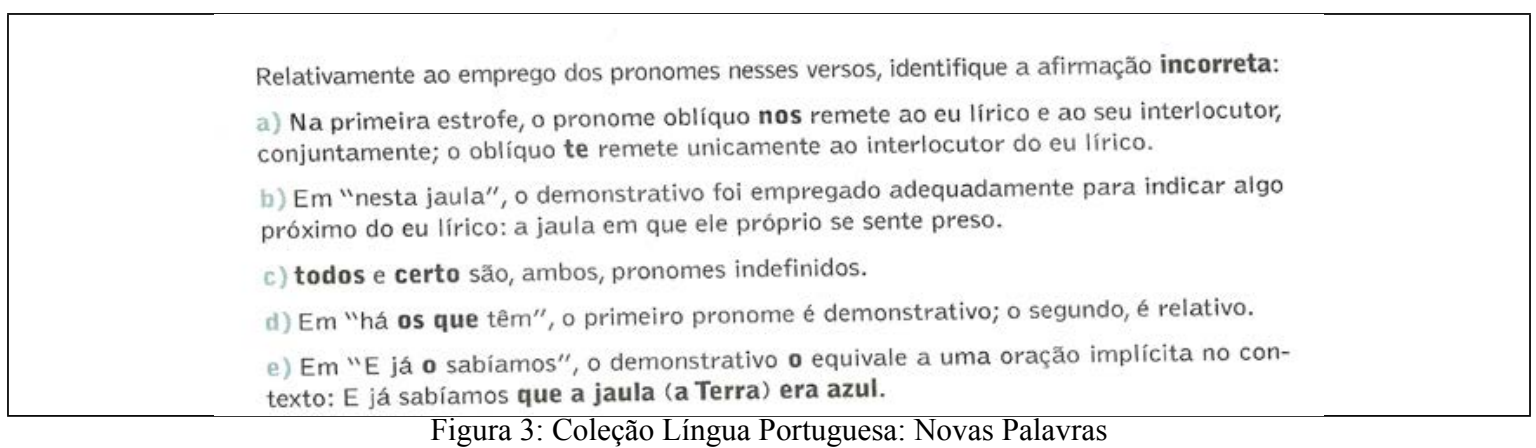

Finalizamos nossa análise destacando que, apesar do grande avanço na Linguística de Texto e nas abordagens de ensino, ainda é possível encontrar livros didáticos que propõem atividades que não apresentam como objetivo um diálogo com a perspectiva sociocognitivo-discursiva; ao contrário, ainda priorizam o enfoque na abordagem normativa, que não incentiva à reflexão dos alunos, mas reforça a reescrita de frases fora de contexto.

Ainda assim, observamos que a maior parte das atividades analisadas contempla, pelo menos, um dos critérios defendidos por Campos (2014) que estão em forte diálogo com a perspectiva sociocognitivo-discursiva, fato que creditamos à intervenção dos PCNs, que já orientam o ensino de língua portuguesa numa perspectiva mais dinâmica, o que prioriza o desenvolvimento da competência comunicativa dos alunos, sinalizando para o surgimento de um ensino contextualizado.

\section{Conclusão}

As análises nos levam a concluir que, apesar dos avanços nos estudos de referenciação e na divulgação de pesquisas, ainda há manuais didáticos que abordam os pronomes pessoais sob uma perspectiva predominantemente normativa; desconsiderando, parcialmente, a junção dos critérios cultural, cognitivo ou prático, defendidos por Campos (2014). Comprovamos que as coleções de livros didáticos do Ensino Médio, como as que serviram de corpus para esta investigação, adotam um tratamento, essencialmente, gramatical no tocante ao ensino das estruturas referenciais dêiticas, nas atividades que propõem.

Dessa forma, acreditamos ter atingindo nosso objetivo principal, qual seja: analisar o tipo de abordagem dispensada aos elementos dêiticos pronominais nos livros didáticos do Ensino Médio, em suas atividades de análise linguística. Constatamos que grande parte dos manuais analisados ainda aplica um tratamento, essencialmente, gramatical, normativo e tangencia a abordagem sociocognitivo-discursiva.

Reforçamos, contudo, que não discriminamos a perspectiva normativa do contexto escolar; ao contrário, defendemos um ensino equilibrado entre as perspectivas normativa e Linguística, nesse caso, sociocognitivo-discursiva que integre os conteúdos nas atividades de análise linguística nos livros didáticos do Ensino Médio, como os elementos dêiticos pronominais com que trabalhamos nesta pesquisa.

Embora as atividades analisadas indiquem que os livros didáticos priorizam um ensino tradicional das formas dêiticas, encontrarmos atividades que demonstram um direcionamento sociocognitivo-discursivo. Acreditamos, ainda, que ao restringimos nossas ações em atividades 
nos livros didáticos e, a partir delas, na observação, na forma como os elementos pronominais dêiticos são apresentados aos alunos do Ensino Médio, essa verificação pode contribuir para a elaboração de atividades orientadas pela abordagem sociocognitivo-discursiva da Linguística de Texto, para que os alunos compreendam o dinamismo desses elementos.

Dessa forma, julgamos que esta pesquisa traz conclusões pertinentes à luz da Linguística Textual, para o ensino das estruturas referenciais dêiticas, que precisam ser abordadas mais extensamente em sala de aula, para que os alunos possam compreender, amplamente, as relações epilinguísticas que estão presentes na construção de sentido dos textos.

Por fim, deixamos para outro momento analisar os efeitos, as consequências de um ensino-aprendizagem sob uma perspectiva como posta atualmente, com foco normativo, predominantemente, pois, para averiguar tal fato, seria necessária uma pesquisa de campo que abrangesse escolas, alunos e professores, tratando-se de um trabalho que demandaria tempo e metodologia adequada.

\section{Referências}

BEAUGRANDE, R. A.; DRESSLER, W. U. Introduction to text linguistics. London: Longman, 1981.

BENVENISTE, E. Problemas de linguística geral I. Tradução de Maria da Glória Novak e Luiza Neri. V.1. São Paulo: Editora da Universidade de São Paulo, 1976.

Problemas de linguística geral II. 2.ed. Tradução de Eduardo Guimarães et al. São Paulo: Pontes, 2006.

BRASIL. Parâmetros Curriculares Nacionais: Ensino Médio. Ministério da Educação. Secretaria de Educação Média e Tecnológica. Brasília: MEC, 2000.

Guia de livros didáticos: PNLD 2012. Língua Portuguesa. Brasília: Ministério da Educação, 2011.

BRONCKART, J. La notion de compétences est-elle pertinente em éducacion? Lécole démocratique, p. 1-10, Nov. 2009.

Atividade de linguagem, textos e discursos. $2^{\text {a }}$ ed. São Paulo: Educ, 2012.

CAMPOS, E. P. Por um novo ensino de gramática: orientações didáticas e sugestões de atividades. Goiânia: Cânone editorial, 2014.

CAVAlCANTE, M. M. A dêixis discursiva. Revista de Letras, Fortaleza, v. 1/2, n. 22, p. 47-55, Jan./Dez. 2000.

Os sentidos do texto. São Paulo: Contexto, 2013.

; CUSTÓDIO FILHO, V; BRITO, P. A. M. Coerência, referenciação e ensino. São Paulo: Cortez, 2014.

CIULLA, A. Os processos de referências e suas funções discursivas - o universo literário dos contos. 2008. 207 f. Tese (Doutorado em Linguística) - Universidade Federal do Ceará, Fortaleza, 2008.

FILLMORE, C. J. Lectures on deixis. California: CSLI Publications Stanford, [1984]1997.

GERALDI. J.W. Linguagem e ensino: exercícios de militância e divulgação. Campinas: Mercado das Letras, 1996. 
HABERMAS, J. Consciência moral e agir comunicativo. Rio de Janeiro: Tempo Brasileiro, 1989. . Agir comunicativo e razão descentralizada. Tradução de Lucia Aragão. Rio de Janeiro: Tempo Brasileiro, 2002.

KOCH, I. G. V. Introdução à linguística textual. São Paulo: Martins Fontes, 2004. . A inter-ação pela linguagem. São Paulo: Contexto, 1993.

LAHUD. M. A propósito da noção de dêixis. São Paulo: Ática, 1979.

LEAL, A. P.B. O processo referencial da dêixis: por uma proposta de recategorização. 2015. $293 \mathrm{f}$. Tese (Doutorado em Linguística) - Universidade Federal do Ceará, Fortaleza, 2015.

LEMOS, A.C. S. Os processos de referenciação dêitica em livros didáticos do Ensino Médio. 2016. 131 f. Dissertação (Mestrado em Linguística) - Programa de Pós-graduação em Linguística, Universidade Federal do Ceará, Fortaleza, 2016.

LYONS, J. Semântica. V. 1. Lisboa: Editorial Presença Ltda., 1977a.

MONDADA, L.; DUBOIS, D. Construção dos objetos de discurso e categorização: uma abordagem dos processos de referenciação. In: CAVALCANTE, M.; RODRIGUES, B.; CIULLA, A. (orgs.). Referenciação. São Paulo: Contexto, 2003. p.17-52.

SOUSA, M. M. F. A organização textual-discursiva nos anúncios de turismo no Ceará. 2005. $213 \mathrm{f}$. Tese (Doutorado em Linguística) - Centro de artes e comunicação, Universidade Federal de Pernambuco, Recife, 2005.

VYGOTSKY, L. S. A formação social da mente: o desenvolvimento dos processos psicológicos superiores. $3^{\text {a }}$.ed. São Paulo: Martins Fontes, 1989.

XAVIER, M. I. O útil e o inútil no ensino de língua materna. In: DALLAZEN, M. I.; XAVIER, M. L. (orgs.). Ensino de língua materna: para além da tradição. Porto Alegre: Mediação, 1998, p. 56-75.

Recebido em 17 de maio de 2016.

Aprovado em 30 de maio de 2016. 